\title{
An Impact Analysis Model of Earnings Management from the Difference between Accounting and Tax Revenue
}

\author{
Yan Zhang ${ }^{1, \text { a }}$ \\ ${ }^{1}$ The Chinese People's Liberation Army Unit 91550, Dalian, 116023, China \\ aemail: zhangyan_DL@163.com
}

Keywords: Tax Revenue; Earnings Management; Impact Analysis Model

\begin{abstract}
The relationship between earnings management and income tax revenue, has always been the focus of domestic and foreign scholars. In this paper, the use of discretionary accrual as a measure of profit, an analytical model is proposed, to investigate the impact of accounting and tax differences on earnings management. Using 2013-2015 years of earnings listed parent company data as a sample, to verify and analyze the reliability of the model.
\end{abstract}

\section{Introduction}

Enterprises tend to carry out earnings management through non-taxable items, which leads to the difference between accounting and tax revenue [1]. Due to earnings management behavior will lead to the current non-taxable items gains and losses, rather than taxable items in the profit and loss of the time difference will lead to the increase of deferred tax [2]. Therefore, we can identify the company's earnings management behavior according to the level of the deferred tax expense [3]. Many foreign research scholars have conducted a systematic study, the results show that the deferred tax index can effectively identify the company's earnings smoothing and avoid the loss of earnings management behavior [4][5].

In this paper, the use of discretionary accrual as a measure of profit, an analytical model is proposed, to investigate the impact of accounting and tax differences on earnings management. Using 2013-2015 years of earnings listed parent company data as a sample, to verify and analyze the reliability of the model.

\section{Proposed model}

Because tax returns are not publicly disclosed, we can only derive taxable income from publicly disclosed financial report data. In fact, because the tax returns may not provide detailed information on the types of business transactions like financial statements, and tax returns can only provide the information, on the contrary, the financial statements can provide more detailed historical information, therefore, the financial report is the tax declaration form can provide more earnings management of listed companies and for tax avoidance our information.

(1) Selection of variables.

In the study of earnings management and accounting income and tax income difference, this paper, in addition to earnings management, but also choose the other two factors to support the study:

Institutional factors: Chinese accounting system and the tax laws and regulations constantly in the process of reform, we selected the provision for impairment of assets, investment income, provision for depreciation and amortization of intangible assets as the institutional factors, the reason is the provisions of the accounting system and tax regulations related to accounting matters are different; they are belong to the annual enterprise income tax return to the adjustment items; can be quantified, and be able to find the corresponding data.

Tax avoidance: on the basis of the control system and earnings management, the residual error of the model-I can be used as a reasonable measure of the company's tax avoidance behavior. But in order to control the company has not observed the characteristics and more accurate access to the 
company's measure of the amount of tax avoidance, the model-II.

(2) Model design.

Based on the above analysis, the following analysis model is put proposed.

The model-I:

$$
\begin{aligned}
B T_{i, t}= & \alpha_{0}+\alpha_{12} \text { MJZZB }_{i, t}+\alpha_{13} \text { TZSY }_{i, t}+\alpha_{14} L Z J_{i, t}+\alpha_{15} \text { WXZCTX }_{i, t}+\alpha_{16} L \text { AGBT }_{i, t}+ \\
& \alpha_{17} \text { TAXCHG }_{i, t}+\alpha_{18} D A_{i, t}+e_{i, t}
\end{aligned}
$$

The model-II:

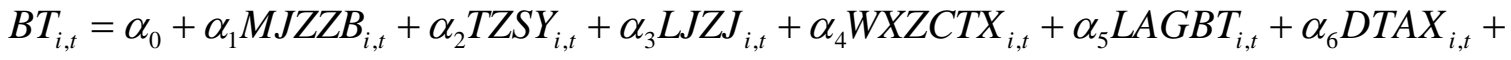

$$
\begin{aligned}
& \alpha_{7} D A_{i, t}+\mu_{i}+e_{i, t}
\end{aligned}
$$

$B T$ : the accounting and tax differences divided by total assets at the beginning of the year, accounting and tax difference $=$ total profit minus taxable income;

MJZZB: adjusted provision for impairment of assets divided by total assets at the beginning of the year;

TZSY: investment income divided by total assets at the beginning of the year;

$L J Z J$ : accrued depreciation divided by total assets at the beginning of the year;

WXZCTX: amortization of intangible assets at the beginning of the year total assets;

LAGBT: previous annual accounting and tax differences divided by total assets at the beginning of the year;

TAXCHG: changes in income tax expenses divided by total assets at the beginning of the year;

$D A$ : discretionary accruals;

I: company;

t:annual.

\section{Empirical test and result analysis}

(1) Sample selection and data sources.

This paper selects listed parent company as the research sample in 2013 - 2015. The amount of the loss due to loss of the company can be in a subsequent year and transfer credits after the annual income tax expense, and inconvenience to accurate calculation after the annual accounting and tax differences, so we only study a profitable company. In order to accurately determine the difference between accounting and tax revenue, the research object is limited to the disclosure of the parent company's report and only the listed parent company with a single tax rate. Data used in the study are from listed companies to disclose the report of the parent company.

As is shown in the Table 1, from 2013 to 2015, accounting and tax differences showed an increasing trend. From the absolute number of view, in 2013 the average difference between accounting and tax revenue was 43 million 143 thousand and 900 yuan, in 2015 expanded to 57 million 708 thousand and 100 yuan. In addition, from the standard deviation, the degree of dispersion of the accounting and tax differences is very high.

Tab.1. Descriptive statistics of difference between accounting and taxation

\begin{tabular}{|c|c|c|c|c|c|c|}
\hline Annual & $\begin{array}{c}\text { sample } \\
\text { size }\end{array}$ & mean & standard deviation & median & maximum & minimum \\
\hline BTD2013 & 654 & 4314.39 & 13230.46 & 1614.33 & 261469.70 & -19914.11 \\
\hline BTD2014 & 728 & 5008.71 & 12789.91 & 1945.48 & 173410.30 & -20511.55 \\
\hline BTD2015 & 790 & 5770.81 & 17055.01 & 1806.74 & 226930.50 & -73909.94 \\
\hline
\end{tabular}

(2) Empirical test and analysis

As stated above, this paper will be able to manipulate the earnings and the line under the project as the ratio of total assets as a measure of earnings management. The estimated steps of the operational accrued profits are as follows: 


\section{Step 1:}

$T A C C=\triangle A S S E T-\triangle C A S H-\triangle L I A B$

TACC is total accrued profit for the company; $\triangle A S S E T$ is annual total assets change for the company; $\triangle C A S H$ is annual monetary fund change for the company; $\triangle L I A B$ is annual changes in liabilities for the company.

Step 2:

$$
D A_{i, t}=a_{1}\left(1 / A S S E T_{i, t}\right)+a_{2}\left(\Delta R E V_{i, t}-\Delta R E C_{i, t}\right)+a_{3}\left(P P E_{i, t}\right)+a_{4}\left(I N T_{i, t}\right)+e_{i, t}
$$

$D A$ is discretionary accrued profit and residual in the model as also; $\triangle R E V$ is main business income change divided by total assets at the beginning of the year; $\triangle R E C$ is changes in accounts receivable divided by total assets at the beginning of the year; $P P E$ is the original value of fixed assets divided by total assets at the beginning of the year; INT is total of intangible assets and other assets divided by total assets of the beginning of the year.

Get the estimated value of $D A$, we begin with a median of 0 and the accounting and tax differences greater than 0 of the company for the Sample, in order to study the relationship between earnings management and accounting and tax differences. Test results are shown in Table 2.

Tab.2. Packet inspection of discretionary accrual

\begin{tabular}{|c|c|c|c|c|c|}
\hline sample1 & mean & $\begin{array}{c}\text { standard } \\
\text { deviation }\end{array}$ & sample2 & mean & $\begin{array}{c}\text { standard } \\
\text { deviation }\end{array}$ \\
\hline 1 & 0.02260 & 0.00280 & 1 & 0.0496 & 0.00453 \\
\hline 0 & 0.0021 & 0.00446 & 0 & -0.0044 & 0.00312 \\
\hline difference & 0.02050 .0205 & 0.005290 & difference & 0.0540 & 0.00549 \\
\hline T value & $3.90^{* * *}$ & & T value & $9.82^{* * *}$ & \\
\hline
\end{tabular}

Similarly, packet inspection of the ratio of total assets under the line. Test results are shown in Table 3.

Tab.3. Grouping test for ratio of total assets under the line item

\begin{tabular}{|c|c|c|c|c|c|}
\hline sample1 & mean & $\begin{array}{c}\text { standard } \\
\text { deviation }\end{array}$ & sample2 & mean & $\begin{array}{c}\text { standard } \\
\text { deviation }\end{array}$ \\
\hline 1 & 0.03886 & 0.00090 & 1 & 0.0605 & 0.00153 \\
\hline 0 & 0.00936 & 0.00111 & 0 & 0.0172 & 0.00065 \\
\hline difference & 0.02950 & 0.00145 & difference & 0.0433 & 0.00166 \\
\hline T value & $20.31^{* * *}$ & & T value & $26.09^{* * *}$ & \\
\hline
\end{tabular}

From the Table 2 and Table 3, through the test of the parameter $T$, accounting and tax differences with the company's earnings management behavior has significant correlation. The higher the difference between accounting and tax revenue of listed companies, the higher the ratio of the company's discretionary accrual and the total assets under the line. This shows that, in recent years, the expansion of Chinese accounting tax differences may be closely related to the company's earnings management behavior.

Now, under the case of the control system and other factors, the relationship between earnings management behavior of the company, and the accounting income - tax revenue differences is inspected. The results are shown in Table 4.

From the regression results of the sample, the variables MJZZB, TZSY, LJZJ, WXZCTX, LAGBT, $D A$ are significant.

The change of investment income, accumulated depreciation, amortization of intangible assets and income tax expenses are the accounting income and tax revenue difference has a significant positive effect, the marginal impact of investment income on accounting income and tax income difference of the maximum. Influence on accounting income and tax income difference of impairment losses on assets is significantly negative, primarily because it is not allowed in the pre tax deduction of asset impairment, so the tax adjustment of assets impairment will result in an increase in taxable income, resulting in reduced accounting income and tax income difference. 
Tab.4. All annual regression results by model-I

\begin{tabular}{|c|c|c|c|c|}
\hline & $2013-2015$ & 2015 & 2014 & 2013 \\
\hline MJZZB & -0.12 & -0.02 & -0.10 & -0.32 \\
\hline TZSY & 0.64 & 0.34 & 0.57 & 0.71 \\
\hline LJZJ & 0.17 & 0.38 & 0.27 & 0.44 \\
\hline WXZCTX & 0.08 & 0.21 & 0.96 & 0.64 \\
\hline LAGBT & 0.22 & -0.90 & 0.37 & 0.23 \\
\hline TAXCHG & 0.45 & 0.72 & -0.85 & -1.20 \\
\hline DA & 0.03 & 0.03 & 0.01 & 0.03 \\
\hline Constant term & -0.01 & -0.01 & -0.01 & -0.01 \\
\hline Sample size & 2172 & 790 & 728 & 654 \\
\hline$R^{2}$ & 0.64 & 0.76 & 0.74 & 0.75 \\
\hline
\end{tabular}

\section{Conclusion}

In this paper, the use of discretionary accrual as a measure of profit, an analytical model is proposed, to investigate the impact of accounting and tax differences on earnings management. Using 2013-2015 years of earnings listed parent company data as a sample, to verify and analyze the reliability of the model. From the perspective of statistical analysis, the difference between accounting system and tax law is an important reason for the difference between accounting income and taxable income. $L A G B T$ is significantly positive, that the previous year's accounting income and tax income difference has significant impact on the accounting income and tax differences. $D A$ is also significantly positive, which shows that in the case of other conditions remain unchanged, earnings management is also one of the reasons that lead to the deviation of accounting profits from taxable income.

\section{References}

[1] Steven F. Cahan, Chen Chen, Li Chen, Nhut Nguyen. Corporate social responsibility and media coverage [J]. Journal of Banking and Finance, 2015.

[2] GREGORY S. MILLER,DOUGLAS J. SKINNER. The Evolving Disclosure Landscape: How Changes in Technology, the Media, and Capital Markets Are Affecting Disclosure [J]. Journal of Accounting Research, 2015(2).

[3] Kathleen Farrell, Emre Unlu, Jin Yu. Stock repurchases as an earnings management mechanism: The impact of financing constraints[J]. Journal of Corporate Finance . 2014.

[4] Diana R. Franz, Hassan R. Impact of proximity to debt covenant violation on earnings management [J]. Review of Accounting Studies, 2014 (1).

[5] ChiaWei Chen, Christos Pantzalis, Jung Chul Park. PRESS COVERAGE AND STOCK PRICE DEVIATION FROM FUNDAMENTAL VALUE [J]. Journal of Financial Research, 2013 (2). 